\title{
DE
} DE GRUYTER OPEN

Arch. Min. Sci., Vol. 60 (2015), No 2, p. 507-516

Electronic version (in color) of this paper is available: http://mining.archives.pl

DOI 10.1515/amsc-2015-0033

\author{
VLADIMIR PAVLOVICH ZHUKOV*, HENRYK OTWINOWSKI**, \\ ANTON NIKOLAEVICH BELYAKOV*, TOMASZ WYLECIAŁ***, \\ VADIM EVGENEVICH MIZONOV*
}

\section{BOLTZMANN EQUATION IN THE MODELING OF MINERAL PROCESSING}

\section{RÓWNANIE BOLTZMANNA W MODELOWANIU PROCESÓW PRZERÓBCZYCH}

The paper presents an application of the Boltzmann kinetic equation to the simultaneous modeling of multi-dimensional processes. This equation defines the evolution of the distribution of the probability density in a given phase space. In the case of a grinding process, the considered phase space is defined by the Cartesian coordinates of particle position, the components of particle velocity and the particle size. The theory of Markov processes is used in the paper to solve the Boltzmann equation for the multi-dimensional space of system states. In order to verify the presented model, research into the simultaneous comminution and movement of material in a drum ball mill was performed. The methodology developed to solve the Boltzmann equation significantly reduces the computational time, which is particularly important in the solution of multi-dimensional problems.

Keywords: Boltzmann equation, mineral processing, comminution, classification, particles transport, matrix model, ball mill

Równanie Boltzmanna jest podstawowym równaniem kinetycznej teorii gazów opisującym ewolucję cząstek w rozrzedzonym gazie. W równaniu tym występuje funkcja gęstości prawdopodobieństwa zmiennej losowej w trójwymiarowej przestrzeni fazowej (funkcja rozkładu). W artykule przedstawiono sposób wykorzystania równania Boltzmanna do analizy procesów przeróbki mechanicznej surowców mineralnych. Wynikiem tej analizy jest matematyczny model występujących równocześnie procesów mielenia, klasyfikacji i transportu materiałów ziarnistych. W tym przypadku równanie Boltzmanna opisuje ewolucję gęstości rozkładu ziaren względem składowych prędkości, współrzędnych kartezjańskich oraz rozmiaru ziarna. W młynie funkcja rozkładu zmienia się w wyniku rozdrabniania i ruchu ziaren, a w klasyfikatorze tylko w wyniku ruchu ziaren. W ogólnym przypadku funkcja rozkładu zależy od: czasu, ruchu ziaren,

* DEPARTMENT OF APPLIED MATHEMATICS, IVANOVO STATE POWER UNIVERSITY, RABFAKOVSKAYA 34, 153003 IVANOVO, RUSSIA. E-MAIL: zhukov@ispu.ru

** INSTITUTE OF THERMAL MACHINERY, CZESTOCHOWA UNIVERSITY OF TECHNOLOGY, ARMII KRAJOWEJ 21, 42-201 CZĘSTOCHOWA, POLAND. E-MAIL: otwinowski@imc.pcz.czest.pl

*** DEPARTMENT OF INDUSTRIAL FURNACES AND ENVIRONMENTAL PROTECTION, CZESTOCHOWA UNIVERSITY OF TECHNOLOGY, ARMII KRAJOWEJ 19, 42-201 CZĘSTOCHOWA, POLAND. E-MAIL: wylecial@wip.pcz.pl 
prędkości ziaren i rozmiaru ziaren, który zmienia się w wyniku rozdrabniania. Uwzględnienie zjawisk losowych wymaga wprowadzenia składowej dyfuzyjnej do równania Boltzmanna. W artykule rozpatrzono zastosowanie równania Boltzmanna do rozdrabniania periodycznego i ciąłłego. W otrzymanych postaciach równania można uwzględnić rzeczywiste warunki technologiczne, co pozwala opisać stanu układu podczas oddzielnych lub jednoczesnych procesów przeróbczych. Przy założeniu jednowymiarowości procesów rozpatrywane zagadnienie sprowadza się do znanych przypadków, analizowanych jako oddzielne procesy. Obliczenia numeryczne wykonano metodą macierzową z wykorzystaniem teorii łańcuchów Markowa. Przedstawiono wyniki obliczeń dla przypadku jednoczesnego rozdrabniania i ruchu ziaren w młynie bębnowym kulowym. Analiza wyników obliczeń wykazała, że przebieg ewolucji stanu układu ziaren jest prawidłowy. W przyszłych badaniach można uwzględnić w równaniu Boltzmanna kształt ziaren, co oznacza wprowadzenie dodatkowych trzech współrzędnych do przestrzeni fazowej. Współrzędne te związane są ze zmianą długości, szerokości i wysokości ziarna.

Słowa kluczowe: równanie Boltzmanna, procesy przeróbcze, rozdrabnianie, klasyfikacja, transport ziaren, model macierzowy, młyn kulowy

\section{Introduction}

The Boltzmann equation is one of the most important equations in non-equilibrium statistical mechanics. This equation describes the evolution of rarefied gas. In rarefied gas there is enough space for particles to have different velocities in one spatial volume element. In a microscopic description of a rarefied neutral gas, the gas particles are moving with a constant velocity until undergoing binary collisions. In a kinetic picture, the properties of the gas are described by the density function in the phase space $f(x, v, \tau)$ called the distribution function. The quantity $f(x, v, \tau) d x d v$ represents the number of particles in the phase-space volume of the element $d x d v$ at time $\tau$. Both $x$ and $v$ are three-dimensional independent variables. The distribution function satisfies the Boltzmann equation, an integro-differential equation, which describes the effect of the free flow and binary collisions between the particles (Cercignani, 1988; Kubo et al., 1991, 1991a; Huang, 1987; Kremer, 2010).

The Boltzmann equation is use to analyse the thermophoresis of adhesive spherical particles immersed in fluid flows. Most theories for thermophoretic force are derived on the basis of the solution to the Boltzmann equation, or some approximations of the Boltzmann equation (Li et al., 2011). Nonlinear kinetic equations with an inflow term and rather general interactions were studied by Eibeck and Wagner (2003). A particular nonlinear kinetic equation with a gradient term was considered by Rjasanow and Wagner (2005). The Boltzmann equation allows to calculate flows of simple gases and gas mixtures in micro- and nanosize channels (Anikin et al., 2012). The kinetic approach was also applied to analyze the long time evolution of the viscous compressible weakly rarefied gas flow (Aristov \& Rovenskaya, 2011). There is lack of using the Boltzmann equation to analyse of mechanical processing of mineral resources. However, it can only find Brożek and co-authors' papers, in which the Boltzmann's distribution is used to modeling of the flotation process (Brożek \& Turno, 2005; Brożek, 2010). In the work of Brożek \& Turno (2005) in the enrichment process it was assumed that the distribution of potential energy along the vertical axis of the separator chamber is in agreement with Boltzmann's distribution. The distribution of air bubble size in flotation cell obtained in heuristic considerations (Brożek, 2010), is based upon an assumption that air flowing into the flotation cell is subject to dispersion in turbulent vortexes of the liquid and the newly formed bubble surfaces have energies whose correspond the Boltzmann's distribution. Brożek and Młynarczykowska assumed that in 
the pneumatic mechanical flotation machine a large air bubble is divided into smaller bubbles according to Boltzmann's law of energy distribution.

\section{Multi-dimensional modeling of mineral processing}

The paper presents a concept for modeling the simultaneous processes of grinding, classification and transferring of granular materials based on the Boltzmann kinetic equation. This equation defines the variation in time of the probability density function of a random variable in the defined phase space. The sought function is the density of the particle distribution with respect to: the Cartesian coordinates, velocity components and size $f(\vec{r}, \vec{v}, x, \tau)$, where: $\vec{r}\left(z_{1}, z_{2}, z_{3}\right)$ - unit vector (versor) of the Cartesian coordinates, $\vec{v}\left(v_{1}, v_{2}, v_{3}\right)$ - vector of particle velocity components, $x$ - particle size, $\tau$ - time. The product of the function $f(\vec{r}, \vec{v}, x, \tau)$ and the phase space $d V=d z_{1} d z_{2} d z_{3} d v_{1} d v_{2} d v_{3} d x$ express the probability of the following event: particle of a size from the elementary range $(x, x+d x)$, staying in the position defined by the elementary coordinates $\left(z_{1}, z_{1}+d z\right),\left(z_{2}, z_{2}+d z_{2}\right),\left(z_{3}, z_{3}+d z_{3}\right)$ at the time $(\tau, \tau+d \tau)$ is moving at the velocity of the elementary components $\left(v_{1}, v_{1}+d v_{1}\right),\left(v_{2}, v_{2}+d v_{2}\right),\left(v_{3}, v_{3}+d v_{3}\right)$. Integrating over all phase space gives the total number of particles in the granular material. In a mill, the distribution function varies as a result of particle size reduction and particle motion, while in a classifier - only as a result of particle motion.

In a general case, the distribution function depends on: the time, particle motion $\operatorname{div}_{r}(\vec{v} f)$, particle velocity $\operatorname{div}_{v}(\vec{a} f)$ and the size variation caused by comminution $\dot{f}_{c}$. The Boltzmann equation in a differential form is as follows:

$$
\frac{\partial f}{\partial \tau}+\frac{\partial v_{1} f}{\partial z_{1}}+\frac{\partial v_{2} f}{\partial z_{2}}+\frac{\partial v_{3} f}{\partial z_{3}}+\frac{\partial a_{1} f}{\partial v_{1}}+\frac{\partial a_{2} f}{\partial v_{2}}+\frac{\partial a_{3} f}{\partial v_{3}}=\dot{f}_{c}
$$

or

$$
\frac{\partial f}{\partial \tau}+\frac{\partial v_{k} f}{\partial z_{k}}+\frac{\partial a_{k} f}{\partial v_{k}}=\dot{f}_{c}, \quad(k=1,2,3)
$$

where: $f(\vec{r}, \vec{v}, x, \tau)$ - the sought density of the particle distribution with respect to the Cartesian coordinates $\vec{r}\left(z_{1}, z_{2}, z_{3}\right)$, velocity components $\vec{v}\left(v_{1}, v_{2}, v_{3}\right)$ and particle size $x ; \vec{a}\left(a_{1}, a_{2}, a_{3}\right)$ - particle acceleration; repetition of the index $\mathrm{k}$ in the numerator and in the denominator means summation with respect to this index. The quantity $\dot{f}_{c}$ on the right-hand side of the equation describes the variation of density of the particle distribution as a result of comminution of particles of the size of $(x, x+d x)$ (which means the transition of those particles to finer classes) and the appearance of particles of the same sizes $(x, x+d x)$, representing the product of comminution of particles of the larger size. By using the comminution model based on the mass balance of particle population (Mizonov et al., 1997), equation (2) takes the following form:

$$
\frac{\partial f}{\partial \tau}+\frac{\partial v_{k} f}{\partial x_{k}}+\frac{\partial a_{k} f}{\partial v_{k}}=-f S(y)+\int_{x}^{x_{\max }} f S(y) b(x, y) d y
$$

where: $S(y)$ - selection function, $b(x, y)$ - breakage function, $x$ - particle size after comminution, $y$ - particle size prior to comminution, $x_{\max }$ - maximum particle size. 
Further on in this paper, two cases of application of equation (3) will be considered:

a) periodical comminution (bowl and roller mill, ring and ball mill)

At zero particle velocities and accelerations, in the case of the periodical comminution, equation (3) will take the form of the known equation of the population mass balance:

$$
\frac{\partial f}{\partial \tau}=-f S(y)+\int_{x}^{x_{\max }} f S(y) b(x, y) d y
$$

b) comminution by attrition

In order to describe the comminution of material by attrition, it is necessary to transform equation (4). Attrition takes place by detaching fine particles from large ones and thereby reducing the particle size of the feed, which means the movement of particle along the coordinate $x$ of its size at a velocity defined as the attrition speed:

$$
\dot{x}=\frac{d x}{d \tau}=\frac{d z_{4}}{d \tau}=v_{4}
$$

In this case the particle motion is described in the four-dimensional space $\left(z_{1}, z_{2}, z_{3}, z_{4}\right)$ $(k=1,2,3,4)$. The formation of fine particles during attrition corresponds to the boundary values of the function $\dot{f}_{c}$ of the following equation:

$$
\frac{\partial f}{\partial \tau}+\frac{\partial v_{k} f}{\partial x_{k}}+\frac{\partial a_{k} f}{\partial v_{k}}=\dot{f}_{c}, \quad(\mathrm{k}=1,2,3,4)
$$

Further generalization of the considered problem may result from taking into account the shape of particles. In that case, three additional coordinates, $x_{4}, x_{5}, x_{6}$, are introduced into the phase space. These coordinates represent the change in the particle length, width and height, while the index $k$ in equation (2) takes the values $k=1,2, \ldots, 6$. Consideration of the random phenomena needs to introduce the diffusion component $\frac{\partial^{2} D_{k} f}{\partial z_{k}^{2}}$
to the equation (1) (Huang, 1987; Bozhenko et al., 2011):

$$
\frac{\partial f}{\partial \tau}+\frac{\partial v_{k} f}{\partial z_{k}}+\frac{\partial a_{k} f}{\partial v_{k}}-\frac{\partial^{2} D_{k} f}{\partial z_{k}^{2}}=\dot{f}_{c}, \quad(k=1,2,3)
$$

In the obtained forms of the Boltzmann equation, specific real technological conditions can be considered, what allows the system state's evolution during either separate or simultaneous comminution, classification and transport processes to be described. Assuming one-dimensional movement or comminution processes, the problem is brought to the known cases which traditionally are solved separately.

\section{Boltzmann equation solution}

A matrix method, using the Markov theory of chains (Berthiaux et al., 2005; Mizonov et al., 2008; Mizonov et al., 2011), was proposed to solve equation (7) numerically. Let $N$ denotes the number of phase coordinates. Along each coordinate of process, the number of the selected cells (or 
steps) is $n_{i}$, where the index $i=1,2, \ldots, N$ denotes the ordinal number of the coordinate. The general number of the considered cells $n$ is equal to the product $N$ of the numbers: $n=n_{1} \cdot n_{2} \cdot \ldots \cdot n_{N}$. The vector of system state $U=\left\{U_{i}\right\}$ with the dimension $1 \cdot n$ is composed of the probabilities of presence in the $i$-th cell, which are equal to the product of the distribution function $f$ and the elementary volume of the phase space: $U_{i}=f \Delta V$. From the normalization condition (being equivalent to the mass conservation law), the sum of these probabilities is equal to unity $\sum_{i} U_{i}=1$.

For the description of the system evolution in time according to equation (7), a random quantity $Y_{i}$ is introduced into each cell, which defines possible transitions:

$$
Y_{i}=\left\{y_{i}, y_{2}, \ldots, y_{m_{i}}\right\}
$$

where: $y_{1}, y_{2}, \ldots, y_{m_{i}}-$ numbers of those cells of the state vector $U$, to which transition from the $i$-th cell is possible with the probability $q_{1}, q_{2}, \ldots, q_{m_{i}}$; $m_{i}$ - number of cells, to which transition from the $i$-th cell is possible. These probabilities form the vector $Q$ :

$$
Q_{i}=\left\{q_{i}, q_{2}, \ldots, q_{m_{i}}\right\}
$$

According to the normalization condition, the sum of the probabilities of all possible transitions equals 1:

$$
\sum_{m_{i}} q_{m_{i}}=1
$$

If transition from the $i$-th cell is possible only to neighbouring cells, then the vector of possible transitions will take the following form:

$$
Y_{i}=\left\{i, i \pm 1, i \pm n_{i}, i \pm n_{i} n_{2}, \ldots, i \pm n_{i} n_{2} \ldots n_{m_{i}-1}\right\}
$$

In equation (11), the index $i$ denotes transition to the considered cell, the indexes $i \pm 1-$ transitions to the right-hand and left-hand adjacent cells, the indexes $i \pm n_{1}-$ transition to the cells situated in the rows above and below the row with the $i$-numbered cell, etc. The probabilities $Q_{i}$ of the transitions, defined by the random quantity $Y_{i}$, are determined on the basis of the physical laws applicable to the courses of the considered processes. For the one-dimensional motion of a particle at the velocity $\mathrm{v}$, the probability of transition to the adjacent cell in time $\Delta \tau$ is determined from the following expression:

$$
q=\bar{v}=\frac{v \Delta \tau}{\Delta x}
$$

where: $\Delta x-$ size of the cell along the $x$ axis.

The change in the particle velocity is defined by acceleration, while the probability of transition to the adjacent cell along the velocity coordinate in time $\Delta \tau$ is:

$$
q=\bar{a}=a \frac{\Delta \tau}{\Delta v}
$$

where: $\Delta v-$ size of the cell along the $v$ axis. 
The change in the particle size is connected with the comminution process. To determine the probability of particle transition to finer classes as a result of comminution, a relationship, based on the population balance, was proposed:

$$
q=\bar{d}=\frac{\left(\bar{x}_{0}-\bar{x}_{1}\right)}{\Delta x}
$$

The difference $\left(\bar{x}_{0}-\bar{x}_{1}\right)$ denotes the change in the average particle size in time $\Delta \tau$. In turn, the change in the average particle size for linear forms of the selection and breakage functions is defined by the following relationship:

$$
\bar{x}_{1}=\frac{\left[1-\exp \left(-\alpha \bar{x}_{0} \Delta \tau\right)\right]}{\alpha \Delta \tau}
$$

where $\alpha$-parameter of the selection function (Mizonov et al. 1997).

The matrix operation was introduced to solve numerically the multi-dimensional equation (7):

$$
U^{k+1}=\hat{p}\left(Y, U^{k}\right)
$$

where the superscript $k$ denotes the number of time step. The matrix operator $\hat{p}$ in equation (16) can be determined through the following identity summation of the probabilities of particle transition from all cells to the considered i-th cell of the system:

$$
U_{i}^{k+1}=\sum_{j=1}^{n} U_{j}^{k} p_{i j}
$$

where $p_{i j}$ - probability of transition from the $j$-th cell to the $i$-th cell.

The probability $p_{i j}$ is determined from the following expression:

$$
p_{i j}=\left\{\begin{array}{lll}
q_{j_{1}} & \text { for } & y_{j_{1}}=i \\
0 & \text { for } & y_{j_{1}} \neq i
\end{array}\right.
$$

where the index $j_{1}=1,2, \ldots, m_{i}$.

Comparing to the traditional multiplication of matrices, equation (16) allows computational time to be reduced due to the elimination of operations with zero elements.

\section{Results and summary}

According to the above algorithm the solution to the Boltzmann equation will be presented on the example of the problem of simultaneous material comminution and movement in a ball tumbling mill. The mill's $z$ axis, the material velocity $v$ along the mill axis and the particle size $x$ were assumed as the coordinates; hence the number of coordinates, along which the process evolution is considered, is equal to three $(N=3)$. The three cells $n_{1}=3, n_{2}=3, n_{3}=3$ were chosen along each coordinate. The considered phase space is presented in Figure 1. 


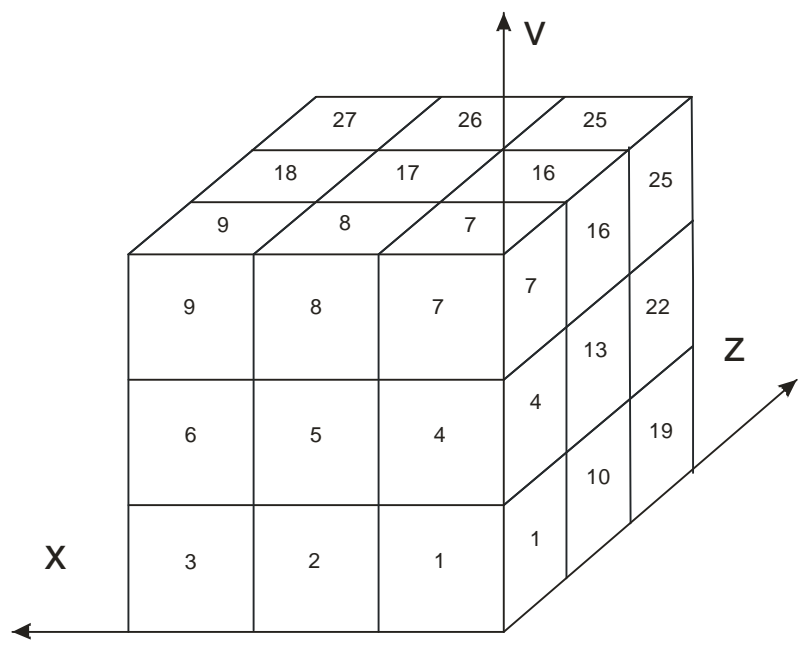

Fig. 1. The phase space in the problem of the simultaneous grinding and movement of material particles in the ball mill (the numbers denote the creation method of the state vector)

Numeration of the cells in Figure 1 represents the method of creating the vector of system state $U$, which contains $n=n_{1} \cdot n_{2} \cdot n_{3}=27$ elements. Comminution is regarded as the reduction of particle sizes or their transition to smaller-size cells with a specified probability $\bar{d}$. At the initial moment, a unit sample of the coarse particles is fed into the mill. Considering the assumed order of cell numerations, the initial state can be described by the vector of system state in the following form:

$$
U_{i}^{0}=\left\{\begin{array}{l}
1 \text { for } i=3 \\
0 \text { for } i \neq 3
\end{array}\right.
$$

Each cell, situated inside the separated phase space, may border on 6 adjacent cells. If the cell is present at the phase space boundary, then the transitions through the boundary are defined by the adequate boundary conditions. In the considered example, an isolated phase volume was selected, from which no particles come out. If the material may only pass to adjacent cells during evolution, then the random quantity $Y$ is expressed applying the following table:

\begin{tabular}{|c|c|c|c|c|c|c|c|}
\hline \hline$Y$ & $i$ & $i-1$ & $i+1$ & $i-n_{1}$ & $i+n_{1}$ & $i-n_{1} n_{2}$ & $i+n_{1} n_{2}$ \\
\hline$Q$ & $1-\bar{d}-\bar{a}-\bar{v}$ & $\bar{d}$ & 0 & 0 & $\bar{a}$ & 0 & $\bar{v}$ \\
\hline
\end{tabular}

The evolution of system state in time, calculated using equation (16) for the initial conditions (19) in the totally isolated phase space (Fig. 1), is presented in Figure 2. In time, the elementary sample of coarse particles passes to the cell with the minimum particle size, the maximum velocity and the maximum coordinate along the mill axis. The change in the contents of three classes in time is presented in Figure 3. The mass fraction of coarse class decreases and the mass fraction of fine class increases. The change in the contents at the outlet of the mill increases with the increasing of the convective mass transfer rate (Fig. 4). 


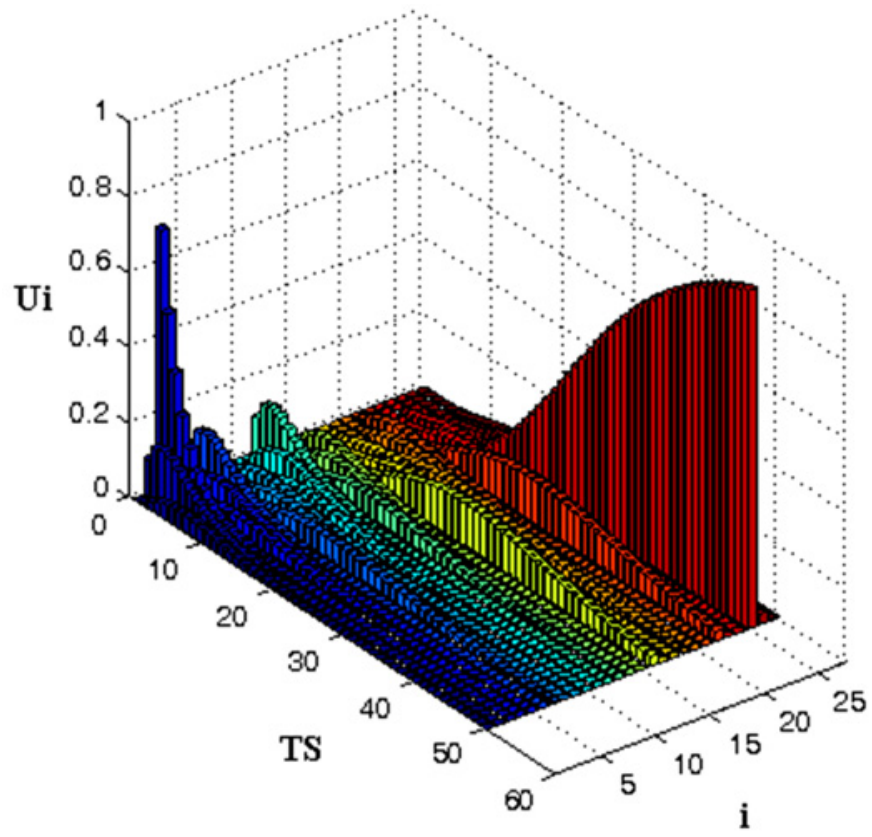

Fig. 2. An evolution of the state vector during material comminution and particle motion at a constant acceleration in the tumbling ball mill: the material passing to the cell at the maximum velocity, the minimum particle size and the maximum coordinate along the mill's axis. Designations of the axes: $i$-cell number consistent with the numeration shown in Figure 1, TS - time step, $U i$ - value of the vector of system state

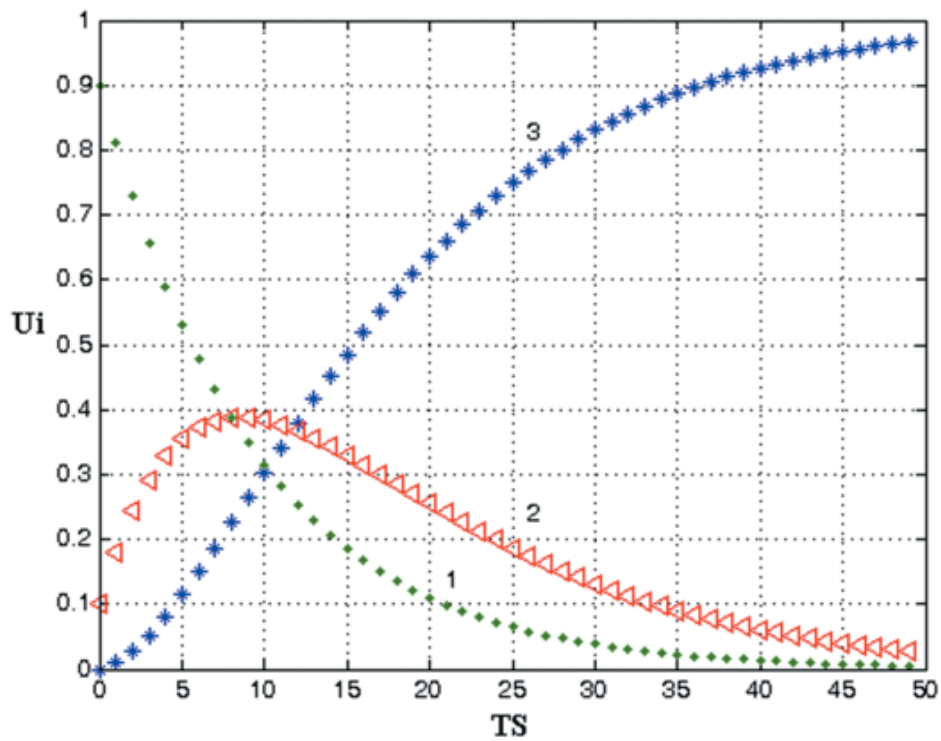

Fig. 3. Change in the contents of a coarse (1), medium (2) and fine (3) classes in time 


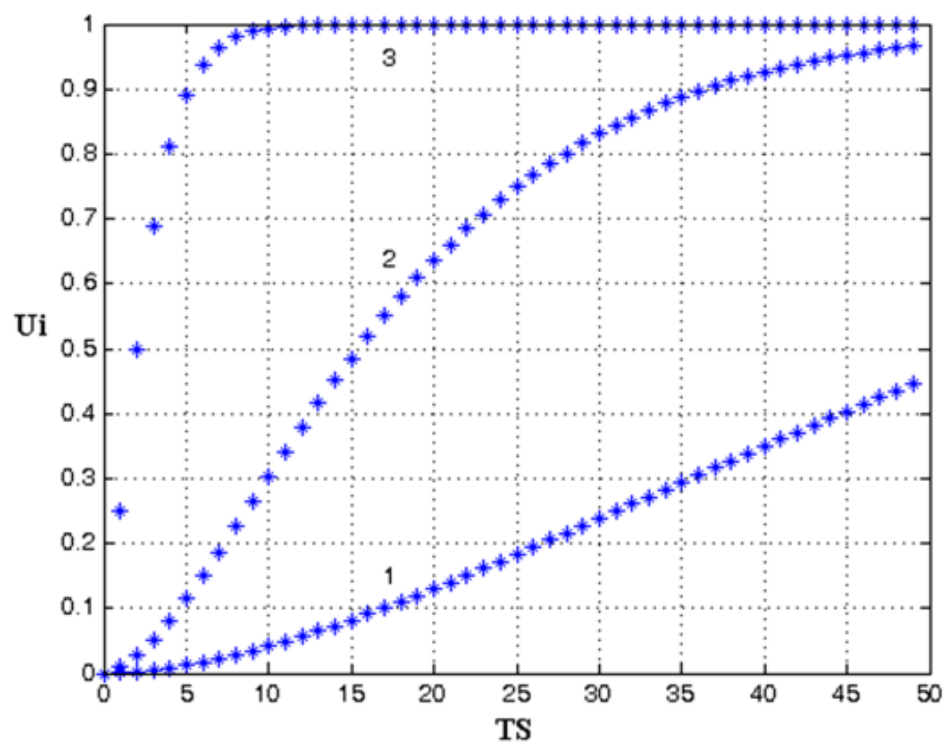

Fig. 4. Change in the contents at the outlet of the mill for different convective mass transfer rates $v$ :

$$
1-v=0.05,2-v=0.1,3-v=0.3
$$

The model presented in the paper enables multi-dimensional simultaneous comminution, classification and transport processes to be analysed. The developed methodology to solve the Boltzmann equation, using operations only on non-zero elements, significantly reduces the computational time, which is particularly important in the solution of multi-dimensional problems.

\section{References}

Anikin Yu.A., Derbakova E.P., Dodulad O.I., Kloss Yu.Yu., Martynov D.V., Rogozin O.A., Shuvalov P.V., Tcheremissine F.G., 2012. Computing of gas flows in micro- and nanoscale channels on the base of the Boltzmann kinetic equation. Procedia Computer Science, 1, 735-744.

Aristov V.V., Rovenskaya O.I., 2011. Application of the Boltzmann kinetic equation to the eddy problems. Computers and Fluids, 50, 189-198.

Berthiaux H., Mizonov V., Zhukov V., 2005. Application of the theory of Markov chains to model different processes in particle technology. Powder Technology, 157, 128-137.

Bozhenko B., Junga R., Pospolita J., 2011. Mathematical model of the milling process on the ring-roller's table. Part I. Mathematical model and it's numeric solution. Arch. Min. Sci., 56, 441-450.

Brożek M., 2010. Probability of particle-bubble collision in pneumo-mechanical flotation cell. Archives of Metallurgy and Materials, 55, 293-304.

Brożek M., Turno A., 2005. The physical model of partition function of the enrichment process in a heavy liquid. Arch. Min. Sci., 50, 289-305.

Cercignani C., 1988. The Boltzmann equation and its applications. Springer-Verlag, Berlin. 


\section{6}

Eibeck A., Wagner W., 2003. Stochastic interacting particle systems and nonlinear kinetic equations. Annals of Applied

Probability, 13, 845-889.

Huang K., 1987. Statistical mechanics (in Polish). PWN, Warszawa.

Kremer G.M., 2010. An Introduction to the Boltzmann Equation and Transport Processes in Gases. Springer-Verlag, Berlin.

Kubo R., Ichimura H., Usui T., Hashitsume N., 1991a. Statistical mechanics. Springer-Verlag, Berlin.

Kubo R., Toda M., Hashitsume N., 1991. Statistical Physics (in Polish). PWN, Warszawa.

Li S., Marshall J.S., Liu G., Yao Q., 2011. Adhesive particulate flow: The discrete-element method and its application in energy and environmental engineering. Progress in Energy and Combustion Science, 37, 633-668.

Mizonov V., Berthiaux H., Arlabosse P., Djerroud D., 2008. Application of the theory of Markov chains to model heat and mass transfer between stochastically moving particulate and gas flows. Granular Matter, 10, 335-340.

Mizonov V., Zaitsev V., Volynskii V., Leznov V., 2001. Modeling the moisture content distribution over a rotating porous cylinder using Markov chains. Chemical Engineering and Technology, 34, 1185-1190.

Mizonov V.E., Ushakov S.G., 1989. Aerodynamic classification of powders (in Russian). Khimiya, Moskva.

Mizonov V.E., Zhukov V.P., Bernotat S., 1997. Simulation of Grinding: New Approaches. ISPU Press, Ivanovo.

Rjasanow S., Wagner W., 2005. Stochastic numerics for the Boltzmann equation. Springer, Berlin.

Received: 15 January 2014 